\title{
Flower-Like Plasma Cell: A Comment
}

\author{
Çiçek Benzeri Plazma Hücresi: Bir Yorum
}

(D) Smeeta Gajendra

Laboratory Oncology Unit, Dr. B.R.A. IRCH, AlIMS, New Delhi, India

\section{To the Editor,}

I read "Flower-Like Plasma Cell Nuclei in Multiple Myeloma" by Sall et al. [1], recently published in this journal. This image report is very descriptive and informative regarding a case of multiple myeloma showing abnormal plasma cells with flowershaped nuclear features. These morphological features can pose a diagnostic dilemma and can mimic lymphoma as "flower cells" or clover-leaf lymphocytes are described typically in HTLV-1-induced adult T-cell leukemia and very rarely in B-cell lymphoma [2]. Plasma cell myeloma or leukemia rarely presents with flower-shaped nuclei and occasional cases of plasma cell leukemia mimicking adult T-cell leukemia/lymphoma were previously reported in the literature $[3,4]$. Upon flowcytometric immunophenotyping, the absence of B-cell or T-cell markers and the presence of plasma cell markers with strong CD38 and CD138 help in differentiating it from lymphoma. The morphological variation of abnormal plasma cells in plasma cell neoplasms is vast, ranging from small lymphocyte-like cells to cleaved, convoluted, monocytoid or multilobated plasma cells to anaplastic pleomorphic large plasma cells, which have been reported previously. A few cases of morphological variants of plasma cell neoplasms, like megakaryocytic, plasmoblastic, or megakaryoblastic mimicking acute leukemia, have also been reported in the literature [5]. The presence of cytoplasmic granulations, vacuolations, crystals (mimicking histiocytes), Auer rod-like inclusions, or cytoplasmic projections has also been noted in the literature. Morphological transformation of plasma cells into multilobated nuclei during the clinical course followed by anaplastic myeloma transformation is also occasionally reported [6]. Circulating cells with cleaved, multilobated, or monocytoid nuclei can be present in a variety of non-hematologic and hematologic disorders, such as reactive plasmacytosis associated with breast carcinoma, metastatic carcinoma, plasma cell leukemia, myelomonocytic leukemia, malignant lymphoma, and multiple myeloma [7]. Autoimmune disorders, hepatitis C, human immunodeficiency virus infections, angioimmunoblastic T-cell lymphoma, and Hodgkin lymphoma are a few examples in which reactive plasmacytosis of bone marrow may reach levels of up to 30\%-50\%. Abnormal plasma cells can be differentiated from normal or reactive plasma cells on flowcytometric immunophenotyping as abnormal plasma cells are mostly CD19-, CD20+, CD27-, CD28+, CD117+, CD56+, CD33+, CD200++, CD307++, CD81-weak to -negative, and clonal for kappa or lambda immunoglobulin [8]. The presence of flower cells in this case demonstrates the use of immunophenotyping and FISH/cytogenetic studies in the classification of atypical, multilobated flower-shaped mononuclear cells and also that flower cell morphology is not restricted only to lymphomas. Sometimes neoplastic plasma cells exhibit cytoplasmic heterogeneity, which poses difficulty in morphological diagnosis and requires ancillary technology like biopsy with immunohistochemistry or immunophenotyping for a definitive diagnosis.

Keywords: Flower cells, Plasma cell myeloma, Flowcytometric immunophenotyping, Immunohistochemistry

Anahtar Sözcükler: Çiçek hücreler, Plazma hücre myelom, Akım sitometrik immün fenotipleme, İmmünohistokimya

Financial Disclosure: The author declared that this study received no financial support.

\section{References}

1. Sall A, Seck M, Samb D, Faye B, Gadji M, Diop S, Touré AO. Flower-like plasma cell nuclei in multiple myeloma. Turk J Hematol 2021;38:153-154.

2. Singh N, Gandhi J, Agrawal N, Panaych A, Tejwani N, Mehta A. Diagnostic dilemma in the morphological detection of flower cells in lymphomas. Indian J Hematol Blood Transfus 2017;33:614-616.

3. De Miguel Sánchez C, Robles de Castro D, Pisón Herrero C, Pérez Persona E, Salcedo Cuesta L, Guinea de Castro JM. Primary plasma cell leukaemia presenting with flower-shaped nuclei. Br J Haematol 2021;193:689.

4. Shibusawa M. Plasma cell leukaemia presenting as flower-shaped plasma cells mimicking adult T-cell leukaemia or lymphoma. Lancet Haematol 2020;7:e270.

5. Liu K, Song H, Shi J, Zhang W, Mu R, Li L. Rare case of plasma cell myeloma with megakaryoblastic morphology mimicking acute leukemia. Indian J Pathol Microbiol 2020;63:485-487.

6. Fujimi A, Nagamachi $Y$, Yamauchi N, Kanisawa Y. Morphological transformation of myeloma cells into multilobated plasma cell nuclei within 7 days in a case of secondary plasma cell leukemia that finally transformed as anaplastic myeloma. Case Rep Hematol 2017;2017:5758368.

7. Yeh YA, Pappas AA, Flick JT, Butch AW. A case of aggressive multiple myeloma with cleaved, multilobated, and monocytoid nuclei, and no serum monoclonal gammopathy. Ann Clin Lab Sci 2000;30:283-288. 
8. Flores-Montero J, de Tute $\mathrm{R}$, Paiva $\mathrm{B}$, Perez JJ, Böttcher $\mathrm{S}$, Wind $\mathrm{H}$, Sanoja L, Puig N, Lecrevisse 0 , Vidriales MB, van Dongen JJ, Orfao A. Immunophenotype of normal vs. myeloma plasma cells: toward antibody panel specifications for MRD detection in multiple myeloma. Cytometry B Clin Cytom 2016;90:61-72.

\title{
REPLY FROM THE AUTHORS
}

We thank Dr. Gajendra for the interest shown in our article. She described in detail the morphological abnormalities, both nuclear and cytoplasmic, of tumoral plasma cells as well as reactive plasma cells.

We fully agree with her that, when in doubt, immunophenotyping is an indispensable tool for distinguishing plasma cells.
Unfortunately, we do not have the cytogenetics to deepen this characterization.

Regards,

Abibatou Sall, Moussa Seck, Diama Samb, Blaise Félix Faye, Macoura Gadji, Saliou Diop, Awa Oumar Touré

\section{Myeloma and Cystoisospora belli}

\author{
Myelom ve Cystoisospora belli
}

(1) Pathum Sookaromdee ${ }^{1}$, (1) Viroj Wiwanitkit2

1 Private Academic Consultant, Bangkok, Thailand

${ }^{2}$ Honorary Professor, Dr. D.Y. Patil University, Pune, India

\section{To the Editor,}

We would like to share our ideas on "Prolonged Severe Watery Diarrhea in a Long-Term Myeloma Survivor: An Unforeseen Infection with Cystoisospora belli" regarding multiple myeloma (MM) patients [1]. Tiryaki et al. [1] concluded that "Parasitic infections are very uncommon... In MM diarrhea points mainly to infection in acute or chronic form," further noting that, to their best knowledge, "this [was] the first case of a patient with MM with C. belli infection" [1]. The incidence of parasitic infection is usually associated with local geography. In developing countries without good hygienic foundations, parasitic infections are common but there is usually no routine screening of MM patients. In a recent report from Brazil, de Castro et al. [2] studied infectious diarrhea in autologous stem cell transplantation cases, including myeloma patients, and found that there were many parasitic infections including $C$. belli infections. In conclusion, we suggest a new recommendation for screening for parasitic infection in any patients with MM and other hematological malignancies.

Keywords: Blood, Cancer, Myeloma, Cystoisospora
Anahtar Sözcükler: Kan, Kanser, Myelom, Cystoisospora

\section{Authorship Contributions}

Concept: P.S., V.W.; Design: P.S., V.W.; Data Collection or Processing: P.S., V.W.; Analysis or Interpretation: P.S., V.W.; Literature Search: P.S., V.W.; Writing: P.S., V.W.

Conflict of Interest: No conflict of interest was declared by the authors.

Financial Disclosure: The authors declared that this study received no financial support.

\section{References}

1. Tiryaki TO, Anıl KU, Büyük M, Yıldırım AY, Atasoy A, Örmeci AC, Beşışık SK. Prolonged severe watery diarrhea in a long-term myeloma survivor: an unforeseen infection with Cystoisospora belli. Turk J Hematol 2021;38:171173.

2. de Castro MD, Chebli JM, Costa U, Alves KRL, Atalla A, Neto AEH. Infectious diarrhea in autologous stem cell transplantation: high prevalence of coccidia in a South American center. Hematol Transfus Cell Ther 2018;40:132-135. 